\section{Kidney \\ Blood Pressure \\ Research}

Kidney Blood Press Res 2014;39:408-419

DOI: 10.1159/000368454

Published ontIne: Uctober 30, 2014

(C) 2014 S. Karger AG, Basel

www.karger.com/kbr

Accepted: August 02, 2014

1423-0143/14/0395-0408\$39.50/0

This is an Open Access article licensed under the terms of the Creative Commons AttributionNonCommercial 3.0 Unported license (CC BY-NC) (www.karger.com/OA-license), applicable to

the online version of the article only. Distribution permitted for non-commercial purposes only.

\title{
Aristolochic Acid Induced Suicidal Erythrocyte Death
}

\author{
Abaid Malik $^{\mathrm{a}}$ Rosi Bissinger ${ }^{\mathrm{a}}$ Salvatrice Calabrò ${ }^{\mathrm{b}} \quad$ Caterina Faggio $^{\mathrm{b}}$ \\ Kashif Jilania,c Florian Lang ${ }^{\mathrm{a}}$
}

aDepartment of Physiology, University of Tuebingen, Germany; 'Department of Biological and Environmental Sciences, University of Messina, Italy; 'Department of Biochemistry, University of Agriculture, 38040, Faisalabad, Pakistan.

Key Words

Phosphatidylserine $\bullet$ Aristolochic Acid $•$ Calcium $•$ Ceramide $•$ Cell volume $•$ Eryptosis

\begin{abstract}
Background/Aims: Aristolochic Acid, a component of Aristolochia plants, has been shown to cause acute kidney injury, renal aristolochic acid nephropathy, Balkan endemic nephropathy, and urothelial carcinoma. Aristolochic acid nephropathy may be associated with severe anemia. The anemia could theoretically be due to stimulation of eryptosis, the suicidal death of erythrocytes characterized by cell shrinkage and cell membrane scrambling with translocation of phosphatidylserine to the erythrocyte cell membrane surface. Signalling involved in the stimulation of eryptosis include increase of cytosolic Ca ${ }^{2+}$-activity $\left(\left[\mathrm{Ca}^{2+}\right]_{\mathrm{i}}\right)$ and formation of ceramide. Methods: Cell volume was estimated from forward scatter, phosphatidylserineexposure from annexin $\mathrm{V}$ binding, $\left[\mathrm{Ca}^{2+}\right]_{i}$ from Fluo3 fluorescence, and ceramide abundance from binding of fluorescent antibodies in flow cytometry. Results: A 48 hours exposure to Aristolochic Acid ( $\geq 75 \mu \mathrm{g} / \mathrm{ml}$ ) was followed by a significant decrease of forward scatter and increase of annexin- $V$-binding. The effects were paralleled by a significant increase of $\left[\mathrm{Ca}^{2+}\right]_{\mathrm{i}}$ and significantly blunted, but not abrogated by removal of extracellular $\mathrm{Ca}^{2+}$. Aristolochic Acid further significantly increased ceramide abundance. Conclusions: Aristolochic Acid triggers eryptosis, an effect at least in part due to entry of extracellular $\mathrm{Ca}^{2+}$ and ceramide formation.
\end{abstract}

Copyright (C) 2014 S. Karger AG, Basel

\section{Introduction}

Aristolochic Acid, a nephrotoxin and carcinogen [1] from plants of the genus Aristolochia [2], may lead to acute kidney injury [3], renal aristolochic acid nephropathy [4-10], Balkan endemic nephropathy $[1,7-9,11,12]$, and urothelial carcinoma $[1,2,4,6-10,13-15]$. Causes 


\section{Kidney \\ Blood Pressure Research}

of Aristolochic Acid intoxication include long-term intake of medicinal herbs containing Aristolochic Acid [16-19] or of flour obtained from wheat contaminated with seeds of Aristolochia clematitis [16]. Aristolochic Acid is considered to be at least partially effective by inducing DNA adduct formation and mutations [1, 4, 8, 9, 13, 14]. Aristolochic acid nephropathy is associated with anemia [20-31].

The anemia may result from eryptosis, the suicidal erythrocyte death characterized by cell shrinkage and cell membrane scrambling with phosphatidylserine translocation to the erythrocyte surface [32]. Phosphatidylserine exposing erythrocytes adhere to respective receptors of phagocytes leading to subsequent engulfment and degradation [32]. Accordingly, phosphatidylserine exposing erythrocytes are rapidly cleared from circulating blood [32] and excessive eryptosis thus leads to anemia as soon as the loss of erythrocytes is not matched by a similar increase of erythrocyte formation. Signalling of eryptosis includes increase of cytosolic $\mathrm{Ca}^{2+}$ concentration $\left(\left[\mathrm{Ca}^{2+}\right]_{\mathrm{i}}\right)$ [33] and ceramide formation [32].

The present study explored, whether Aristolochic Acid triggers eryptosis, and if so, whether it influences $\left[\mathrm{Ca}^{2+}\right]_{i}$ or ceramide abundance.

\section{Materials and Methods}

\section{Erythrocytes, solutions and chemicals}

Fresh Li-Heparin-anticoagulated blood samples were kindly provided by the blood bank of the University of Tübingen. The blood was drawn from healthy individuals. The study is approved by the ethics committee of the University of Tübingen (184/2003V). The blood was centrifuged at $120 \mathrm{rcf}$ for 20 minutes at $23^{\circ} \mathrm{C}$ and the platelets- and leukocytes-containing supernatant was disposed. Erythrocytes were washed in Ringer solution containing (in mM) $125 \mathrm{NaCl}, 5 \mathrm{KCl}, 1 \mathrm{MgSO}_{4}, 32 \mathrm{~N}$-2-hydroxyethylpiperazine-N-2-ethanesulfonic acid (HEPES), 5 glucose, $1 \mathrm{CaCl}_{2}$ (pH 7.4). For the experiments, erythrocytes were incubated in vitro at a hematocrit of $0.4 \%$ at $37^{\circ} \mathrm{C}$ for $48 \mathrm{~h}$. Erythrocytes were exposed to Aristolochic Acid (Sigma-Aldrich, Hamburg, Germany) in concentrations of $0,25,50,75$ and $100 \mu \mathrm{g} / \mathrm{ml}$, respectively). In $\mathrm{Ca}^{2+}$-free Ringer solution, $1 \mathrm{mM} \mathrm{CaCl}_{2}$ was substituted by $1 \mathrm{mM}$ glycol-bis(2-aminoethylether)-N,N,N',N'-tetraacetic acid (EGTA).

\section{FACS analysis of annexin-V-binding and forward scatter}

After incubation under the respective experimental condition, $50 \mu \mathrm{l}$ cell suspension was washed in Ringer solution containing $5 \mathrm{mM} \mathrm{CaCl}_{2}$ and then stained with Annexin-V-FITC (1:200 dilution; ImmunoTools, Friesoythe, Germany) in this solution at $37^{\circ} \mathrm{C}$ for $20 \mathrm{~min}$ under protection from light. In the following, the forward scatter (FSC) of the cells was determined, and annexin-V fluorescence intensity was measured with an excitation wavelength of $488 \mathrm{~nm}$ and an emission wavelength of $530 \mathrm{~nm}$ on a FACS Calibur (BD, Heidelberg, Germany).

\section{Measurement of intracellular $\mathrm{Ca}^{2+}$}

After incubation, erythrocytes were washed in Ringer solution and then loaded with Fluo-3/AM (Biotium, Hayward, USA) in Ringer solution containing $5 \mathrm{mM} \mathrm{CaCl}_{2}$ and $5 \mu \mathrm{M}$ Fluo-3/AM. The cells were incubated at $37^{\circ} \mathrm{C}$ for $30 \mathrm{~min}$ and washed twice in Ringer solution containing $5 \mathrm{mM} \mathrm{CaCl} \mathrm{Cl}_{2}$ The Fluo-3/ AM-loaded erythrocytes were resuspended in $200 \mu \mathrm{l}$ Ringer. Then, $\mathrm{Ca}^{2+}$-dependent fluorescence intensity was measured with an excitation wavelength of $488 \mathrm{~nm}$ and an emission wavelength of $530 \mathrm{~nm}$ on a FACS Calibur.

\section{Determination of ceramide formation}

For the determination of ceramide, a monoclonal antibody-based assay was used. After incubation, cells were stained for 1 hour at $37^{\circ} \mathrm{C}$ with $1 \mu \mathrm{g} / \mathrm{ml}$ anti ceramide antibody (clone MID 15B4, Alexis, Grünberg, Germany) in PBS containing $0.1 \%$ bovine serum albumin (BSA) at a dilution of 1:10. The samples were washed twice with PBS-BSA. Subsequently, the cells were stained for 30 minutes with polyclonal fluorescein isothiocyanate (FITC) conjugated goat anti-mouse IgG and IgM specific antibody (Pharmingen, Hamburg, Germany) diluted 1:50 in PBS-BSA. Unbound secondary antibody was removed by repeated washing with 


\section{Kidney Blood Pressure Research}

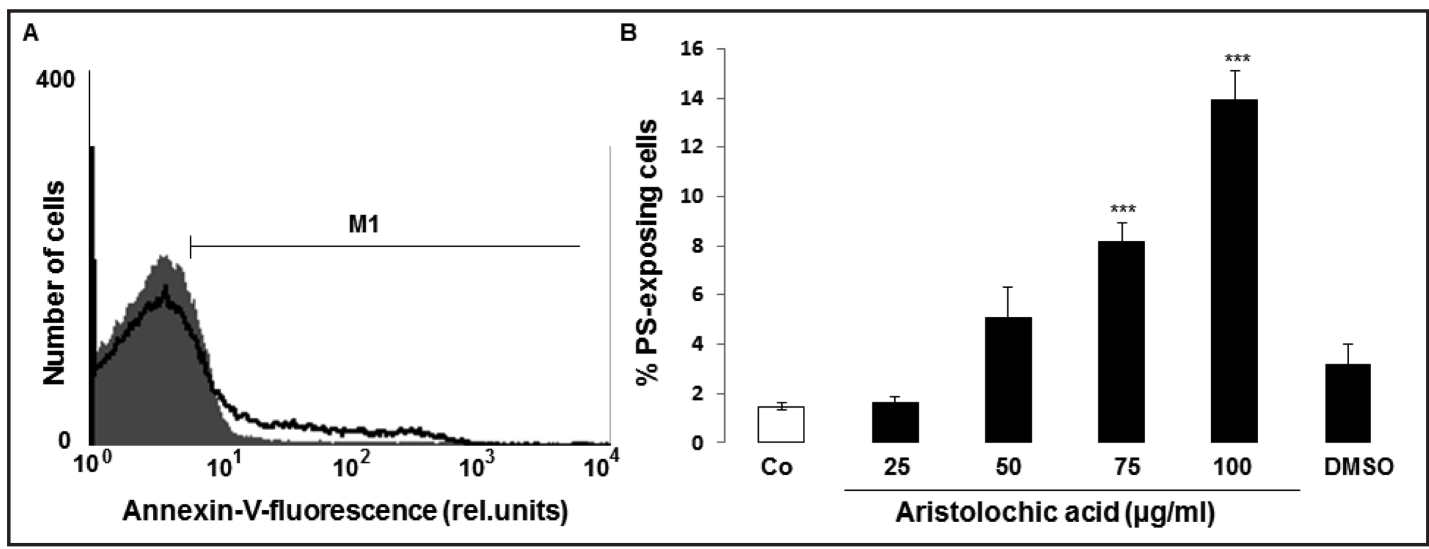

Fig. 1. Effect of Aristolochic Acid on phosphatidylserine exposure. A: Original histogram of annexin V binding of erythrocytes following exposure for 48 hours to Ringer solution without (grey shadow) and with (black line) presence of $100 \mu \mathrm{g} / \mathrm{ml}$ Aristolochic Acid. B: Arithmetic means \pm SEM $(\mathrm{n}=10)$ of erythrocyte annexin-V-binding following incubation for 48 hours to Ringer solution without (white bar) or with (black bars) presence of Aristolochic Acid $(25-100 \mu \mathrm{g} / \mathrm{ml})$ or, for comparison, DMSO (0.8\%) alone. ${ }^{* * *}(\mathrm{p}<0.001)$ indicates significant difference from the absence of Aristolochic Acid (ANOVA).

PBS-BSA. The samples were then analyzed by flow cytometric analysis with an excitation wavelength of 488 $\mathrm{nm}$ and an emission wavelength of $530 \mathrm{~nm}$.

\section{Measurement of hemolysis}

For the determination of hemolysis, the samples were centrifuged ( $3 \mathrm{~min}$ at $1600 \mathrm{RPM}$, room temperature) after incubation, and the supernatants were harvested. As a measure of hemolysis, the hemoglobin $(\mathrm{Hb})$ concentration of the supernatant was determined photometrically at $405 \mathrm{~nm}$. The absorption of the supernatant of erythrocytes lysed in distilled water was defined as $100 \%$ hemolysis.

\section{Statistics}

Data are expressed as arithmetic means \pm SEM. As indicated in the figure legends, statistical analysis was made using ANOVA with Tukey's test as post-test and $t$ test as appropriate. The number of different blood samples studied is given as n. Since different erythrocyte specimens used in distinct experiments are differently susceptible to triggers of eryptosis, the same erythrocyte specimens have been used for control and experimental conditions.

\section{Results}

The present study explored the possibility that Aristolochic Acid triggers eryptosis, the suicidal death of erythrocytes. The major hallmark of eryptosis is cell membrane scrambling with translocation of phosphatidylserine from the cell interior to the cell surface. Phosphatidylserine exposing erythrocytes were identified by binding of annexin- $V$ and detected by flow cytometry. As shown in Fig. 1, a 48 hours exposure to Aristolochic Acid was followed by an increase of annexin-V-binding erythrocytes, an effect reaching statistical significance at $75 \mu \mathrm{g} / \mathrm{ml}$ Aristolochic Acid concentration.

Hemoglobin concentration in the supernatant was determined in order to estimate the effect of Aristolochic Acid exposure on hemolysis. According to hemoglobin concentration in the supernatant, a 48 hours incubation with 0, 25, 50, 75 and $100 \mu \mathrm{g} / \mathrm{ml}$ Aristolochic Acid resulted in hemolysis of $1.84 \pm 0.24 \%, 6.20 \pm 3.01 \%, 13.53 \pm 2.80 \%, 16.29 \pm 2.64$ and 18.36 $\pm 3.34 \%(\mathrm{n}=7)$, respectively.

Eryptosis is further typically associated with cell shrinkage. Accordingly, cell volume was estimated from forward scatter in flow cytometry. As illustrated in Fig. 2, a 48 hours 


\section{Kidney Blood Pressure Research}

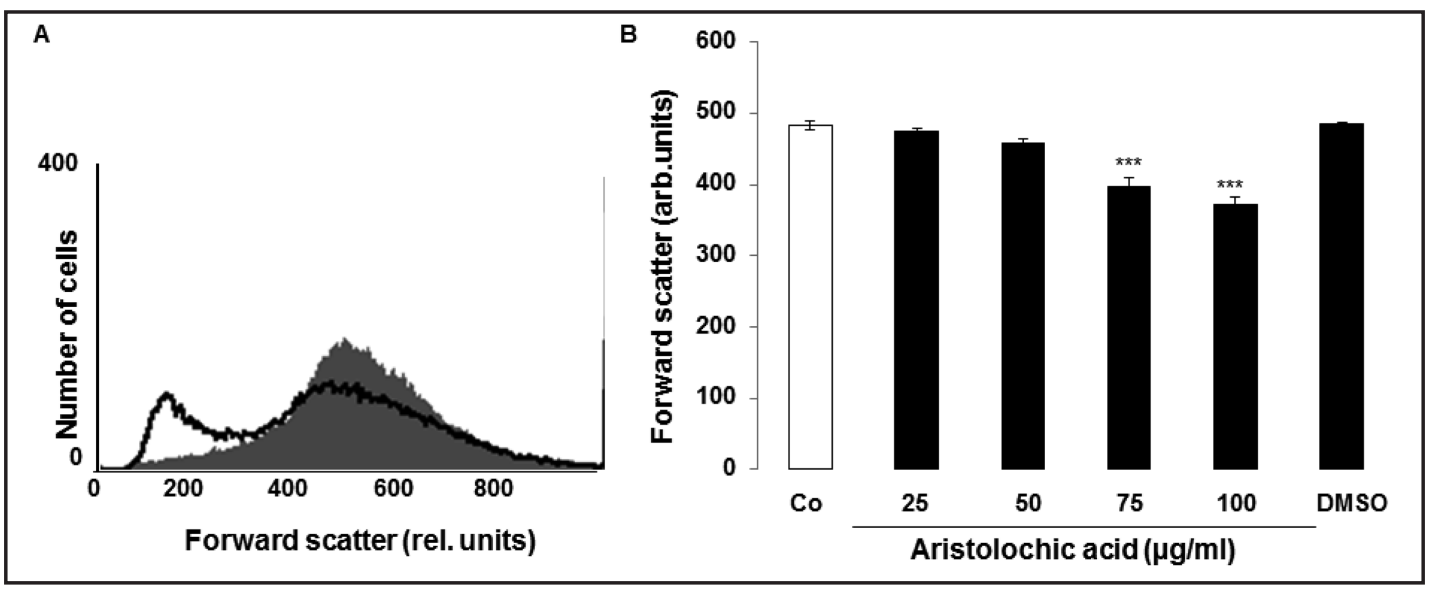

Fig. 2. Effect of Aristolochic Acid on erythrocyte forward scatter. A: Original histogram of forward scatter of erythrocytes following exposure for 48 hours to Ringer solution without (grey shadow) and with (black line) presence of $100 \mu \mathrm{g} / \mathrm{ml}$ Aristolochic Acid. B: Arithmetic means \pm SEM $(n=10)$ of the normalized erythrocyte forward scatter (FSC) following incubation for 48 hours to Ringer solution without (white bar) or with (black bars) Aristolochic Acid $(25-100 \mu \mathrm{g} / \mathrm{ml})$ or, for comparison, DMSO (0.8 \%) alone. *** $(\mathrm{p}<0.001)$ indicates significant difference from the absence of Aristolochic Acid (ANOVA).

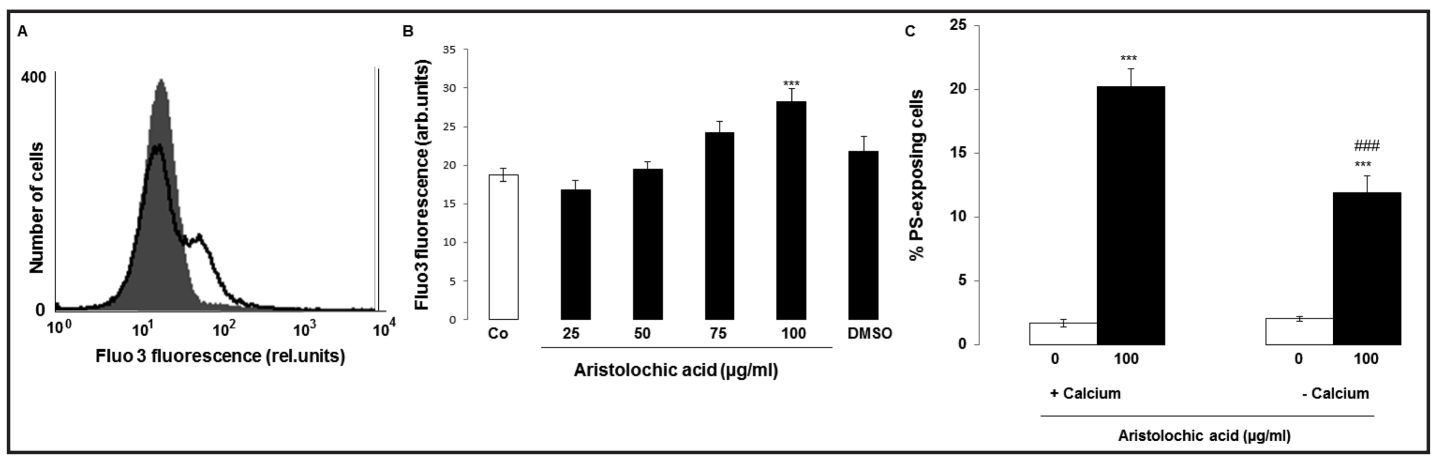

Fig. 3. Effect of Aristolochic Acid on erythrocyte cytosolic $\mathrm{Ca}^{2+}$ concentration. A: Original histogram of Fluo3 fluorescence in erythrocytes following exposure for 48 hours to Ringer solution without (grey shadow) and with (black line) presence of $100 \mu \mathrm{g} / \mathrm{ml}$ Aristolochic Acid. B: Arithmetic means \pm SEM ( $\mathrm{n}=10)$ of the Fluo3 fluorescence (arbitrary units) in erythrocytes exposed for 48 hours to Ringer solution without (white bar) or with (black bars) Aristolochic Acid (25-100 $\mu \mathrm{g} / \mathrm{ml}$ ) or, for comparison, DMSO (0.8 \%) alone. C: Arithmetic means \pm SEM $(n=6)$ of the percentage of annexin-V-binding erythrocytes after a 48 hours treatment with Ringer solution without (white bars) or with (black bars) $100 \mu \mathrm{g} / \mathrm{ml}$ Aristolochic Acid in the presence (left bars, Plus Calcium) and absence (right bars, Minus Calcium) of calcium. ${ }^{* *}(\mathrm{p}<0.001)$ indicates significant difference from the respective values in the absence of Aristolochic Acid, \#\#\# $(p<0.001)$ indicates significant difference from the respective values in the presence of calcium (ANOVA).

exposure to Aristolochic Acid decreased forward scatter, an effect reaching statistical significance at $75 \mu \mathrm{g} / \mathrm{ml}$ Aristolochic Acid concentration.

Cell membrane scrambling and cell shrinkage could both have resulted from an increase of cytosolic $\mathrm{Ca}^{2+}$ activity $\left(\left[\mathrm{Ca}^{2+}\right]_{\mathrm{i}}\right)$. Accordingly, Fluo3 fluorecence was employed to estimate alterations of $\left[\mathrm{Ca}^{2+}\right]_{\mathrm{i}}$. To this end, erythrocytes were loaded with Fluo3-AM and Fluo3 fluorescence determined by flow cytometry. As shown in Fig. 3 (A, B), a 48 hours exposure of human erythrocytes to Aristolochic Acid increased Fluo3 fluorescence, an effect reaching statistical significance at $100 \mu \mathrm{g} / \mathrm{ml}$ Aristolochic Acid. Further experiments were designed to test, whether the cell membrane scrambling following Aristolochic Acid treatment required 


\section{Kidney Blood Pressure Research}

A

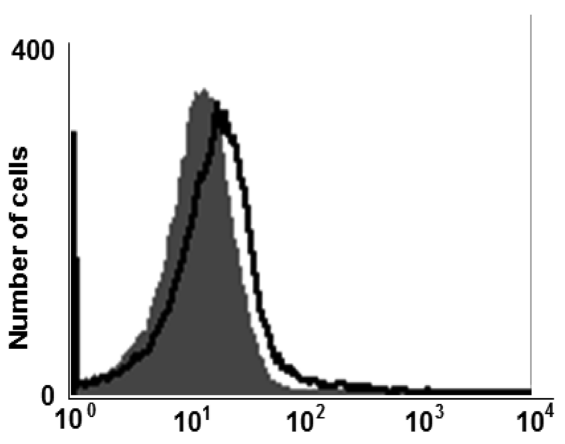

anti-Ceramide FITC-fluorescence (rel.units)

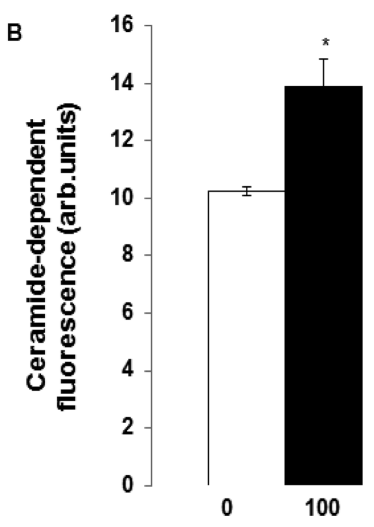

Aristolochic acid $(\mu \mathrm{g} / \mathrm{ml})$

Fig. 4. Effect of Aristolochic Acid on ceramide abundance. A: Original histogram of anti-ceramide FITC fluorescence in erythrocytes after exposure for 48 hours to Ringer solution without (grey shadow) and with (black line) presence of $100 \mu \mathrm{g} / \mathrm{ml}$ Aristolochic Acid. B: Arithmetic means \pm SEM $(\mathrm{n}=4)$ of ceramide abundance at the erythrocyte surface following incubation for 48 hours to Ringer solution without (white bar) or with (black bar) presence of Aristolochic Acid $(100 \mu \mathrm{g} / \mathrm{ml}) . *(\mathrm{p}<0.05)$ indicates significant difference from the absence of Aristolochic Acid (ANOVA).

entry of extracellular $\mathrm{Ca}^{2+}$. To this end, erythrocytes were exposed for 48 hours to $100 \mu \mathrm{g} /$ $\mathrm{ml}$ Aristolochic Acid in the presence or nominal absence of extracellular $\mathrm{Ca}^{2+}$. As illustrated in Fig. 3C, the effect of Aristolochic Acid on annexin-V-binding was significantly blunted in the nominal absence of $\mathrm{Ca}^{2+}$. However, Aristolochic Acid still significantly increased the percentage of annexin $\mathrm{V}$ binding erythrocytes in the nominal absence of extracellular $\mathrm{Ca}^{2+}$. Thus, the effect of Aristolochic Acid on cell membrane scrambling did not fully depend on $\mathrm{Ca}^{2+}$ entry.

Since cell membrane scrambling may be triggered even at constant $\left[\mathrm{Ca}^{2+}\right]_{\mathrm{i}}$ by ceramide, further experiments were performed to explore, whether Aristolochic Acid increases ceramide formation. The abundance of ceramide at the erythrocyte surface was determined utilizing an anti-ceramide antibody. As illustrated in Fig. 4, a 48 hours exposure to $100 \mu \mathrm{g} / \mathrm{ml}$ Aristolochic Acid significantly increased the ceramide abundance at the erythrocyte surface.

\section{Discussion}

The present study discloses a novel effect of Aristolochic Acid, i.e. the triggering of eryptosis, the suicidal death of erythrocytes characterized by cell shrinkage and cell membrane scrambling with translocation of phosphatidylserine to the erythrocyte surface. Aristolochic Acid concentrations similar to those required for the triggering of eryptosis have previously been reported to occur in vivo [34]. However, nephrotoxicity may be observed at lower plasma concentrations [35]. It must be kept in mind that the anemia following Aristolochic Acid intoxication could at least partially result from impaired formation of new erythrocytes and/or indirect stimulation of erythrocyte death, e.g. due to chronic kidney disease [36, 37].

Aristolochic Acid was at least partially effective through stimulation of $\mathrm{Ca}^{2+}$ entry with subsequent increase of cytosolic $\mathrm{Ca}^{2+}$ activity $\left(\left[\mathrm{Ca}^{2+}\right]_{\mathrm{i}}\right) . \mathrm{Ca}^{2+}$ is a major trigger of eryptosis [32]. $\mathrm{Ca}^{2+}$ stimulates cell membrane scrambling by some illdefined mechanism and triggers cell shrinkage presumably by activation of $\mathrm{Ca}^{2+}$ sensitive $\mathrm{K}^{+}$channels, $\mathrm{K}^{+}$exit, cell membrane hyperpolarisation, $\mathrm{Cl}^{-}$exit and thus cellular loss of $\mathrm{KCl}$ with osmotically obliged 


\section{Kidney Blood Pressure Research}

water [33]. Moreover, Aristolochic Acid is effective in part by increasing the abundance of ceramide, another well known trigger of eryptosis [32]. Stimulators of ceramide formation in erythrocytes include platelet activating factor (PAF), which is generated by a pohospholipase A2 [38]. In other cell types Aristolochic Acid has been shown to inhibit phospholipase A2 [39, 40]. It remains to be shown whether Aristolochic Acid stimulates ceramide formation in other cell types. Possibly, $\mathrm{Ca}^{2+}$ entry and ceramide production contribute to the known stimulation of kidney cell apoptosis [4, 25, 41-70]. In nucleated cells, Aristolochic Acid is, however, at least partially effective by further mechanisms, such as formation of DNA adducts [71]. Erythrocytes are devoid of nuclei and thus would not be affected by DNA adduct forming activities.

The present observations do not rule out the involvement of further signalling pathways in the triggering of eryptosis by Aristolochic Acid. Signalling possibly contributing to stimulation of eryptosis include caspase activation [72-76], lack of AMP activated kinase AMPK [77] or cGMP-dependent protein kinase [78], inhibition of p21 activated kinase PAK2 [79] or sorafenib [80] and sunitinib [81] sensitive kinases as well as stimulation of casein kinase $1 \alpha$ [82, 83], Janus-activated kinase JAK3 [84], protein kinase C [85] or p38 kinase [86].

Eryptosis is a physiological mechanism removing defective erythrocytes prior to hemolysis [32]. Eryptotic cell shrinkage [33] counteracts swelling of the defective cells thus minimizing hemolysis with release of cellular hemoglobin. Released hemoglobin may otherwise undergo glomerular filtration and subsequent precipitation and occlusion of renal tubules [87].

Excessive eryptosis may, however lead to anemia, a known side effect of Aristolochic Acid [20-31]. Phosphatidylserine exposing erythrocytes are rapidly cleared from circulating blood [32]. To the extent that the clearance of eryptotic erythrocytes is not compensated by similar increase of erythrocyte formation, anemia develops [32]. Moreover, the adherence of phosphatidylserine exposing erythrocytes to endothelial receptors [88] compromises microcirculation [88-93]. In addition, phosphatidylserine exposing erythrocytes foster blood clotting and thrombosis $[89,94,95]$. Derangement of renal microcirculation may contribute to the toxic effect of Aristolochic Acid on the kidney.

The stimulation of eryptosis by Aristolochic Acid may be enhanced in patients suffering from disorders facilitating eryptosis [32], such as diabetes [76, 96, 97], renal insufficiency [36, 37], hemolytic uremic syndrome [98], dehydration [99], sepsis [100], malaria [101], sickle cell disease [101], Wilson's disease [102], iron deficiency [103], malignancy [104], phosphate depletion [105], and metabolic syndrome [106]. Moreover, Aristolochic Acid induced eryptosis may be augmented by additional exposure to other eryptosis triggering xenobiotics [32, 81, 86, 106-130]. Those substances include several uremic toxins [32, 36, $113,128,131]$ and phosphate [132]. Thus, Aristolochic Acid induced uremia could sensitize erythrocytes to the proeryptotic effect of Aristolochic Acid.

\section{Conclusion}

Aristolochic Acid is a powerful stimulator of eryptosis, the suicidal erythrocyte death. Signalling involved in the stimulation of eryptosis by Aristolochic Acid include stimulation of $\mathrm{Ca}^{2+}$ entry and ceramide formation.

\section{Disclosure Statement}

The authors of this manuscript state that they do not have any conflict of interests and nothing to disclose. 


\section{Kidney \\ Blood Pressure Research}

Malik/Bissinger/Calabrò/Faggio/Jilani/Lang: Aristolochic Acid-Induced Eryptosis

\section{Acknowledgements}

The authors acknowledge the meticulous preparation of the manuscript by Tanja Loch. The study was supported by the Deutsche Forschungsgemeinschaft and the Open Access Publishing Fund of Tuebingen University.

\section{References}

-1 Stiborova M, Martinek V, Frei E, Arlt VM, Schmeiser HH: Enzymes metabolizing aristolochic acid and their contribution to the development of aristolochic acid nephropathy and urothelial cancer. Curr Drug Metab 2013;14:695-705.

-2 Wu F, Wang T: Risk assessment of upper tract urothelial carcinoma related to aristolochic acid. Cancer Epidemiol Biomarkers Prev 2013;22:812-820.

- Liangos 0: Drugs and AKI. Minerva Urol Nefrol 2012;64:51-62.

4 Allard T, Wenner T, Greten HJ, Efferth T: Mechanisms of herb-induced nephrotoxicity. Curr Med Chem 2013;20:2812-2819.

5 Asif M: A brief study of toxic effects of some medicinal herbs on kidney. Adv Biomed Res 2012;1:44.

-6 Gluhovschi G, Margineanu F, Velciov S, Gluhovschi C, Bob F, Petrica L, Bozdog G, Trandafirescu V, Modalca M: Fifty years of Balkan endemic nephropathy in Romania: some aspects of the endemic focus in the Mehedinti county. Clin Nephrol 2011;75:34-48.

-7 Gokmen MR, Cosyns JP, Arlt VM, Stiborova M, Phillips DH, Schmeiser HH, Simmonds MS, Cook HT, Vanherweghem JL, Nortier JL, Lord GM: The epidemiology, diagnosis, and management of aristolochic acid nephropathy: a narrative review. Ann Intern Med 2013;158:469-477.

8 Grollman AP: Aristolochic acid nephropathy: Harbinger of a global iatrogenic disease. Environ Mol Mutagen 2013;54:1-7.

-9 Jha V: Herbal medicines and chronic kidney disease. Nephrology (Carlton) 2010;15:10-17.

10 Stiborova M, Frei E, Arlt VM, Schmeiser HH: Knockout and humanized mice as suitable tools to identify enzymes metabolizing the human carcinogen aristolochic acid. Xenobiotica 2014;44:135-145.

-11 Pepeljnjak S, Klaric MS: “Suspects” in etiology of endemic nephropathy: aristolochic acid versus mycotoxins. Toxins (Basel) 2010;2:1414-1427.

$>12$ Wernerson A, Wijkstrom J, Elinder CG: Update on endemic nephropathies. Curr Opin Nephrol Hypertens 2014;23:232-238.

13 Hollstein M, Moriya M, Grollman AP, Olivier M: Analysis of TP53 mutation spectra reveals the fingerprint of the potent environmental carcinogen, aristolochic acid. Mutat Res 2013;753:41-49.

14 Kucab JE, Phillips DH, Arlt VM: Linking environmental carcinogen exposure to TP53 mutations in human tumours using the human TP53 knock-in (Hupki) mouse model. FEBS J 2010;277:2567-2583.

15 Michl J, Ingrouille MJ, Simmonds MS, Heinrich M: Naturally occurring aristolochic acid analogues and their toxicities. Nat Prod Rep 2014;31:676-693.

16 Debelle FD, Vanherweghem JL, Nortier JL: Aristolochic acid nephropathy: a worldwide problem. Kidney Int 2008;74:158-169.

17 Lao YM, Jiang JG, Yan L: Application of metabonomic analytical techniques in the modernization and toxicology research of traditional Chinese medicine. Br J Pharmacol 2009;157:1128-1141.

18 Shaohua Z, Ananda S, Ruxia Y, Liang R, Xiaorui C, Liang L: Fatal renal failure due to the Chinese herb "GuanMu Tong" (Aristolochia manshuriensis): autopsy findings and review of literature. Forensic Sci Int 2010;199:e5-7.

19 Zhang J, Zhang L, Wang W, Wang H, China National Survey of Chronic Kidney Disease Working G: Association between aristolochic acid and CKD: a cross-sectional survey in China. Am J Kidney Dis 2013;61:918-922.

20 Chang CH, Wang YM, Yang AH, Chiang SS: Rapidly progressive interstitial renal fibrosis associated with Chinese herbal medications. Am J Nephrol 2001;21:441-448.

-21 Chen D, Tang Z, Luo C, Chen H, Liu Z: Clinical and pathological spectrums of aristolochic acid nephropathy. Clin Nephrol 2012;78:54-60. 


\section{Kidney \\ Blood Pressure Research}

22 Cosyns JP: Aristolochic acid and 'Chinese herbs nephropathy': a review of the evidence to date. Drug Saf 2003;26:33-48.

23 Cosyns JP, Dehoux JP, Guiot Y, Goebbels RM, Robert A, Bernard AM, van Ypersele de Strihou C: Chronic aristolochic acid toxicity in rabbits: a model of Chinese herbs nephropathy? Kidney Int 2001;59:21642173.

24 Cosyns JP, Jadoul M, Squifflet JP, De Plaen JF, Ferluga D, van Ypersele de Strihou C: Chinese herbs nephropathy: a clue to Balkan endemic nephropathy? Kidney Int 1994;45:1680-1688.

25 Hamano Y, Aoki T, Shirai R, Hatano M, Kimura R, Ogawa M, Yokosuka O, Ueda S: Low-dose darbepoetin alpha attenuates progression of a mouse model of aristolochic acid nephropathy through early tubular protection. Nephron Exp Nephrol 2010;114:e69-81.

-26 Hong YT, Fu LS, Chung LH, Hung SC, Huang YT, Chi CS: Fanconi's syndrome, interstitial fibrosis and renal failure by aristolochic acid in Chinese herbs. Pediatr Nephrol 2006;21:577-579.

27 Kazama I, Matsubara M, Michimata M, Suzuki M, Hatano R, Sato H, Ito S: Adult onset Fanconi syndrome: extensive tubulo-interstitial lesions and glomerulopathy in the early stage of Chinese herbs nephropathy. Clin Exp Nephrol 2004;8:283-287.

28 Kong PI, Chiu YW, Kuo MC, Chen SC, Chang JM, Tsai JC, Hwang SJ, Chen HC: Aristolochic acid nephropathy due to herbal drug intake manifested differently as Fanconi's syndrome and end-stage renal failure - a 7-year follow-up. Clin Nephrol 2008;70:537-541.

29 Nishimagi E, Kawaguchi Y, Terai C, Kajiyama H, Hara M, Kamatani N: Progressive interstitial renal fibrosis due to Chinese herbs in a patient with calcinosis Raynaud esophageal sclerodactyly telangiectasia (CREST) syndrome. Intern Med 2001;40:1059-1063.

-30 Yang CS, Lin CH, Chang SH, Hsu HC: Rapidly progressive fibrosing interstitial nephritis associated with Chinese herbal drugs. Am J Kidney Dis 2000;35:313-318.

-31 Zhao YY, Zhang L, Mao JR, Cheng XH, Lin RC, Zhang Y, Sun WJ: Ergosta-4,6,8(14),22-tetraen-3-one isolated from Polyporus umbellatus prevents early renal injury in aristolochic acid-induced nephropathy rats. J Pharm Pharmacol 2011;63:1581-1586.

-32 Lang E, Qadri SM, Lang F: Killing me softly - suicidal erythrocyte death. Int J Biochem Cell Biol 2012;44:1236-1243.

33 Lang PA, Kaiser S, Myssina S, Wieder T, Lang F, Huber SM: Role of $\mathrm{Ca}^{2+}$-activated $\mathrm{K}^{+}$channels in human erythrocyte apoptosis. Am J Physiol Cell Physiol 2003;285:C1553-C1560.

-34 Tsai TH, Chou CJ, Lin LC, Tsai WJ, Chen CF: Determination of Aristolochic Acid in Rabbit Plasma by High-Performance Liquid Chromatography with Photodiode-Array Ultraviolet Detection and Its Pharmacokinetics Application. J Liquid Chromatogr 1993;16:1173-1182.

35 Chen SM, Fan MY, Tseng CC, Ho Y, Hsu KY: Pharmacokinetics and nephrotoxicity of aristolochic acid in rabbits. Toxicon 2007;50:180-188.

-36 Abed M, Artunc F, Alzoubi K, Honisch S, Baumann D, Foller M, Lang F: Suicidal erythrocyte death in endstage renal disease. J Mol Med (Berl) 2014;92:871-879.

37 Myssina S, Huber SM, Birka C, Lang PA, Lang KS, Friedrich B, Risler T, Wieder T, Lang F: Inhibition of erythrocyte cation channels by erythropoietin. J Am Soc Nephrol 2003;14:2750-2757.

-38 Lang PA, Kempe DS, Tanneur V, Eisele K, Klarl BA, Myssina S, Jendrossek V, Ishii S, Shimizu T, Waidmann M, Hessler G, Huber SM, Lang F, Wieder T: Stimulation of erythrocyte ceramide formation by plateletactivating factor. J Cell Sci 2005;118:1233-1243.

-39 Meyer SG, Karow W, de Groot H: 2n-fatty acids from phosphatidylcholine label sphingolipids--a novel role of phospholipase A2? Biochim Biophys Acta 2005;1735:68-78.

40 Pastorino JG, Simbula G, Yamamoto K, Glascott PA, Jr., Rothman RJ, Farber JL: The cytotoxicity of tumor necrosis factor depends on induction of the mitochondrial permeability transition. J Biol Chem 1996;271:29792-29798.

-41 Arlt VM, Zuo J, Trenz K, Roufosse CA, Lord GM, Nortier JL, Schmeiser HH, Hollstein M, Phillips DH: Gene expression changes induced by the human carcinogen aristolochic acid I in renal and hepatic tissue of mice. Int J Cancer 2011;128:21-32.

42 Balachandran P, Wei F, Lin RC, Khan IA, Pasco DS: Structure activity relationships of aristolochic acid analogues: toxicity in cultured renal epithelial cells. Kidney Int 2005;67:1797-1805.

43 Chen T, Guo L, Zhang L, Shi L, Fang H, Sun Y, Fuscoe JC, Mei N: Gene expression profiles distinguish the carcinogenic effects of aristolochic acid in target (kidney) and non-target (liver) tissues in rats. BMC Bioinformatics 2006; 7:S20. 


\section{Kidney \\ Blood Pressure Research}

Malik/Bissinger/Calabrò/Faggio/Jilani/Lang: Aristolochic Acid-Induced Eryptosis

44 Chen YY, Chiang SY, Wu HC, Kao ST, Hsiang CY, Ho TY, Lin JG: Microarray analysis reveals the inhibition of nuclear factor-kappa B signaling by aristolochic acid in normal human kidney (HK-2) cells. Acta Pharmacol Sin 2010;31:227-236.

-45 Chen YY, Chung JG, Wu HC, Bau DT, Wu KY, Kao ST, Hsiang CY, Ho TY, Chiang SY: Aristolochic acid suppresses DNA repair and triggers oxidative DNA damage in human kidney proximal tubular cells. Oncol Rep 2010;24:141-153.

-46 Hsin YH, Cheng CH, Tzen JT, Wu MJ, Shu KH, Chen HC: Effect of aristolochic acid on intracellular calcium concentration and its links with apoptosis in renal tubular cells. Apoptosis 2006;11:2167-2177.

47 Kuo CC, Huang JK, Chou CT, Cheng JS, Tsai JY, Fang YC, Hsu SS, Liao WC, Chang HT, Ho CM, Jan CR: Effect of bisphenol A on $\mathrm{Ca}(2+)$ fluxes and viability in Madin-Darby canine renal tubular cells. Drug Chem Toxicol 2011;34:454-461.

48 Li J, Zhang L, Jiang Z, Shu B, Li F, Bao Q, Zhang L: Toxicities of aristolochic acid I and aristololactam I in cultured renal epithelial cells. Toxicol In Vitro 2010;24:1092-1097.

49 Liu M, Yang X, Fan J, Zhang R, Wu J, Zeng Y, Nie J, Yu X: Altered tight junctions and fence function in NRK52E cells induced by aristolochic acid. Hum Exp Toxicol 2012;31:32-41.

50 Liu MC, Maruyama S, Mizuno M, Morita Y, Hanaki S, Yuzawa Y, Matsuo S: The nephrotoxicity of Aristolochia manshuriensis in rats is attributable to its aristolochic acids. Clin Exp Nephrol 2003;7:186-194.

-51 Liu Q, Wang Q, Yang X, Shen X, Zhang B: Differential cytotoxic effects of denitroaristolochic acid II and aristolochic acids on renal epithelial cells. Toxicol Lett 2009;184:5-12.

-52 Odell AF, Odell LR, Askham JM, Alogheli H, Ponnambalam S, Hollstein M: A novel p53 mutant found in iatrogenic urothelial cancers is dysfunctional and can be rescued by a second-site global suppressor mutation. J Biol Chem 2013;288:16704-16714.

53 Okada H, Watanabe Y, Inoue T, Kobayashi T, Kanno Y, Shiota G, Nakamura T, Sugaya T, Fukamizu A, Suzuki $\mathrm{H}$ : Transgene-derived hepatocyte growth factor attenuates reactive renal fibrosis in aristolochic acid nephrotoxicity. Nephrol Dial Transplant 2003;18:2515-2523.

54 Pozdzik AA, Salmon IJ, Debelle FD, Decaestecker C, Van den Branden C, Verbeelen D, Deschodt-Lanckman MM, Vanherweghem JL, Nortier JL: Aristolochic acid induces proximal tubule apoptosis and epithelial to mesenchymal transformation. Kidney Int 2008;73:595-607.

-55 Romanov V, Whyard T, Bonala R, Johnson F, Grollman A: Glutamate dehydrogenase requirement for apoptosis induced by aristolochic acid in renal tubular epithelial cells. Apoptosis 2011;16:1217-1228.

56 Shieh P, Tsai ML, Chiu MH, Chen YO, Yi NL, Jan CR: Independent effects of the broccoli-derived compound sulforaphane on Ca2+ influx and apoptosis in Madin-Darby canine renal tubular cells. Chin J Physiol 2010;53:215-222.

57 Stemmer K, Ellinger-Ziegelbauer H, Ahr HJ, Dietrich DR: Molecular characterization of preneoplastic lesions provides insight on the development of renal tumors. Am J Pathol 2009;175:1686-1698.

58 Wang W, Zhang J: Protective effect of erythropoietin against aristolochic acid-induced apoptosis in renal tubular epithelial cells. Eur J Pharmacol 2008;588:135-140.

59 Wang Z, Zhao J, Zhang J, Wei J, Zhang J, Huang Y: Protective effect of BMP-7 against aristolochic acidinduced renal tubular epithelial cell injury. Toxicol Lett 2010;198:348-357.

-60 Yang CC, Wu CT, Chen LP, Hung KY, Liu SH, Chiang CK: Autophagy induction promotes aristolochic acid-Iinduced renal injury in vivo and in vitro. Toxicology 2013;312:63-73.

61 Yang H, Dou Y, Zheng X, Tan Y, Cheng J, Li L, Du Y, Zhu D, Lou Y: Cysteinyl leukotrienes synthesis is involved in aristolochic acid I-induced apoptosis in renal proximal tubular epithelial cells. Toxicology 2011;287:3845.

62 Yu FY, Wu TS, Chen TW, Liu BH: Aristolochic acid I induced oxidative DNA damage associated with glutathione depletion and ERK1/2 activation in human cells. Toxicol In Vitro 2011;25:810-816.

63 Yuan SY, Yang CR, Cheng CL, Hsu SL, Liao JW, Lin CC, Chou YY, Cheng YW: Comparative nephrotoxicity of aristolochic acid and tetrandrine in vitro and in vivo. Int J Toxicol 2011;30:35-46.

64 Zeng Y, Li S, Wu J, Chen W, Sun H, Peng W, Yu X, Yang X: Autophagy inhibitors promoted aristolochic acid I induced renal tubular epithelial cell apoptosis via mitochondrial pathway but alleviated nonapoptotic cell death in mouse acute aritolochic acid nephropathy model. Apoptosis 2014;19:1215-1224.

65 Zeng Y, Yang X, Wang J, Fan J, Kong Q, Yu X: Aristolochic acid I induced autophagy extenuates cell apoptosis via ERK 1/2 pathway in renal tubular epithelial cells. PLoS One 2012;7:e30312.

66 Zeng Y, Zhang R, Wu J, Liu M, Peng W, Yu X, Yang X: Organic anion transporter 1 (OAT1) involved in renal cell transport of aristolochic acid I. Hum Exp Toxicol 2012;31:759-770. 


\section{Kidney \\ Blood Pressure Research}

Malik/Bissinger/Calabrò/Faggio/Jilani/Lang: Aristolochic Acid-Induced Eryptosis

67 Zhang L, Li J, Jiang Z, Sun L, Mei X, Yong B, Zhang L: Inhibition of aquaporin-1 expression by RNAi protects against aristolochic acid I-induced apoptosis in human proximal tubular epithelial (HK-2) cells. Biochem Biophys Res Commun 2011;405:68-73.

68 Zhang Y, Lemasters J, Herman B: Secretory group IIA phospholipase A(2) generates anti-apoptotic survival signals in kidney fibroblasts. J Biol Chem 1999;274:27726-27733.

-69 Zhou L, Fu P, Huang XR, Liu F, Lai KN, Lan HY: Activation of p53 promotes renal injury in acute aristolochic acid nephropathy. J Am Soc Nephrol 2010;21:31-41.

-70 Zhu S, Wang Y, Jin J, Guan C, Li M, Xi C, Ouyang Z, Chen M, Qiu Y, Huang M, Huang Z: Endoplasmic reticulum stress mediates aristolochic acid I-induced apoptosis in human renal proximal tubular epithelial cells. Toxicol In Vitro 2012;26:663-671.

71 Schmeiser HH, Nortier JL, Singh R, da Costa GG, Sennesael J, Cassuto-Viguier E, Ambrosetti D, Rorive S, Pozdzik A, Phillips DH, Stiborova M, Arlt VM: Exceptionally long-term persistence of DNA adducts formed by carcinogenic aristolochic acid I in renal tissue from patients with aristolochic acid nephropathy. Int J Cancer 2014;135:502-507.

72 Bhavsar SK, Bobbala D, Xuan NT, Foller M, Lang F: Stimulation of suicidal erythrocyte death by alpha-lipoic acid. Cell Physiol Biochem 2010;26:859-868.

73 Foller M, Huber SM, Lang F: Erythrocyte programmed cell death. IUBMB Life 2008;60:661-668.

-74 Foller M, Mahmud H, Gu S, Wang K, Floride E, Kucherenko Y, Luik S, Laufer S, Lang F: Participation of leukotriene C(4) in the regulation of suicidal erythrocyte death. J Physiol Pharmacol 2009;60:135-143.

75 Lau IP, Chen H, Wang J, Ong HC, Leung KC, Ho HP, Kong SK: In vitro effect of CTAB- and PEG-coated gold nanorods on the induction of eryptosis/erythroptosis in human erythrocytes. Nanotoxicology 2012;6:847856.

76 Maellaro E, Leoncini S, Moretti D, Del Bello B, Tanganelli I, De Felice C, Ciccoli L: Erythrocyte caspase-3 activation and oxidative imbalance in erythrocytes and in plasma of type 2 diabetic patients. Acta Diabetol 2013;50:489-495.

77 Foller M, Sopjani M, Koka S, Gu S, Mahmud H, Wang K, Floride E, Schleicher E, Schulz E, Munzel T, Lang F: Regulation of erythrocyte survival by AMP-activated protein kinase. FASEB J 2009;23:1072-1080.

78 Foller M, Feil S, Ghoreschi K, Koka S, Gerling A, Thunemann M, Hofmann F, Schuler B, Vogel J, Pichler B, Kasinathan RS, Nicolay JP, Huber SM, Lang F, Feil R: Anemia and splenomegaly in cGKI-deficient mice. Proc Natl Acad Sci USA 2008;105:6771-6776.

79 Zelenak C, Foller M, Velic A, Krug K, Qadri SM, Viollet B, Lang F, Macek B: Proteome analysis of erythrocytes lacking AMP-activated protein kinase reveals a role of PAK2 kinase in eryptosis. J Proteome Res 2011;10:1690-1697.

80 Lupescu A, Shaik N, Jilani K, Zelenak C, Lang E, Pasham V, Zbidah M, Plate A, Bitzer M, Foller M, Qadri SM, Lang F: Enhanced Erythrocyte Membrane Exposure of Phosphatidylserine Following Sorafenib Treatment: An in vivo and in vitro Study. Cell Physiol Biochem 2012;30:876-888.

81 Shaik N, Lupescu A, Lang F: Sunitinib-sensitive suicidal erythrocyte death. Cell Physiol Biochem 2012;30:512-522.

82 Kucherenko Y, Zelenak C, Eberhard M, Qadri SM, Lang F: Effect of casein kinase 1alpha activator pyrvinium pamoate on erythrocyte ion channels. Cell Physiol Biochem 2012;30:407-417.

83 Zelenak C, Eberhard M, Jilani K, Qadri SM, Macek B, Lang F: Protein kinase CK1alpha regulates erythrocyte survival. Cell Physiol Biochem 2012;29:171-180.

84 Bhavsar SK, Gu S, Bobbala D, Lang F: Janus kinase 3 is expressed in erythrocytes, phosphorylated upon energy depletion and involved in the regulation of suicidal erythrocyte death. Cell Physiol Biochem 2011;27:547-556.

85 Klarl BA, Lang PA, Kempe DS, Niemoeller OM, Akel A, Sobiesiak M, Eisele K, Podolski M, Huber SM, Wieder T, Lang F: Protein kinase C mediates erythrocyte "programmed cell death" following glucose depletion. Am J Physiol Cell Physiol 2006;290:C244-C253.

-86 Gatidis S, Zelenak C, Fajol A, Lang E, Jilani K, Michael D, Qadri SM, Lang F: p38 MAPK activation and function following osmotic shock of erythrocytes. Cell Physiol Biochem 2011;28:1279-1286.

87 Harrison HE, Bunting H, Ordway NK, Albrink WS: The Pathogenesis of the Renal Injury Produced in the Dog by Hemoglobin or Methemoglobin. J Exp Med 1947;86:339-356.

88 Borst O, Abed M, Alesutan I, Towhid ST, Qadri SM, Foller M, Gawaz M, Lang F: Dynamic adhesion of eryptotic erythrocytes to endothelial cells via CXCL16/SR-PSOX. Am J Physiol Cell Physiol 2012;302:C644-C651. 


\section{Kidney \\ Blood Pressure Research}

Malik/Bissinger/Calabrò/Faggio/Jilani/Lang: Aristolochic Acid-Induced Eryptosis

-89 Andrews DA, Low PS: Role of red blood cells in thrombosis. Curr Opin Hematol 1999;6:76-82.

90 Closse C, Dachary-Prigent J, Boisseau MR: Phosphatidylserine-related adhesion of human erythrocytes to vascular endothelium. Br J Haematol 1999;107:300-302.

91 Gallagher PG, Chang SH, Rettig MP, Neely JE, Hillery CA, Smith BD, Low PS: Altered erythrocyte endothelial adherence and membrane phospholipid asymmetry in hereditary hydrocytosis. Blood 2003;101:46254627.

-92 Pandolfi A, Di Pietro N, Sirolli V, Giardinelli A, Di Silvestre S, Amoroso L, Di Tomo P, Capani F, Consoli A, Bonomini M: Mechanisms of uremic erythrocyte-induced adhesion of human monocytes to cultured endothelial cells. J Cell Physiol 2007;213:699-709.

$\$ 93$ Wood BL, Gibson DF, Tait JF: Increased erythrocyte phosphatidylserine exposure in sickle cell disease: flow-cytometric measurement and clinical associations. Blood 1996;88:1873-1880.

$\$ 94$ Chung SM, Bae ON, Lim KM, Noh JY, Lee MY, Jung YS, Chung JH: Lysophosphatidic acid induces thrombogenic activity through phosphatidylserine exposure and procoagulant microvesicle generation in human erythrocytes. Arterioscler Thromb Vasc Biol 2007;27:414-421.

$\$ 95$ Zwaal RF, Comfurius P, Bevers EM: Surface exposure of phosphatidylserine in pathological cells. Cell Mol Life Sci 2005;62:971-988.

$\$ 96$ Calderon-Salinas JV, Munoz-Reyes EG, Guerrero-Romero JF, Rodriguez-Moran M, Bracho-Riquelme RL, Carrera-Gracia MA, Quintanar-Escorza MA: Eryptosis and oxidative damage in type 2 diabetic mellitus patients with chronic kidney disease. Mol Cell Biochem 2011;357:171-179.

-97 Nicolay JP, Schneider J, Niemoeller OM, Artunc F, Portero-Otin M, Haik G, Jr., Thornalley PJ, Schleicher E, Wieder T, Lang F: Stimulation of suicidal erythrocyte death by methylglyoxal. Cell Physiol Biochem 2006;18:223-232.

-98 Lang PA, Beringer O, Nicolay JP, Amon O, Kempe DS, Hermle T, Attanasio P, Akel A, Schafer R, Friedrich B, Risler T, Baur M, Olbricht CJ, Zimmerhackl LB, Zipfel PF, Wieder T, Lang F: Suicidal death of erythrocytes in recurrent hemolytic uremic syndrome. J Mol Med (Berl) 2006;84:378-388.

99 Abed M, Feger M, Alzoubi K, Pakladok T, Frauenfeld L, Geiger C, Towhid ST, Lang F: Sensitization of erythrocytes to suicidal erythrocyte death following water deprivation. Kidney Blood Press Res 2013;37:567-578.

100 Kempe DS, Akel A, Lang PA, Hermle T, Biswas R, Muresanu J, Friedrich B, Dreischer P, Wolz C, Schumacher U, Peschel A, Gotz F, Doring G, Wieder T, Gulbins E, Lang F: Suicidal erythrocyte death in sepsis. J Mol Med 2007;85:269-277.

101 Foller M, Bobbala D, Koka S, Huber SM, Gulbins E, Lang F: Suicide for survival - death of infected erythrocytes as a host mechanism to survive malaria. Cell Physiol Biochem 2009;24:133-140.

102 Lang PA, Schenck M, Nicolay JP, Becker JU, Kempe DS, Lupescu A, Koka S, Eisele K, Klarl BA, Rubben H, Schmid KW, Mann K, Hildenbrand S, Hefter H, Huber SM, Wieder T, Erhardt A, Haussinger D, Gulbins E, Lang F: Liver cell death and anemia in Wilson disease involve acid sphingomyelinase and ceramide. Nat Med 2007;13:164-170.

103 Kempe DS, Lang PA, Duranton C, Akel A, Lang KS, Huber SM, Wieder T, Lang F: Enhanced programmed cell death of iron-deficient erythrocytes. FASEB J 2006;20:368-370.

104 Qadri SM, Mahmud H, Lang E, Gu S, Bobbala D, Zelenak C, Jilani K, Siegfried A, Foller M, Lang F: Enhanced suicidal erythrocyte death in mice carrying a loss-of-function mutation of the adenomatous polyposis coli gene. J Cell Mol Med 2012;16:1085-1093.

105 Birka C, Lang PA, Kempe DS, Hoefling L, Tanneur V, Duranton C, Nammi S, Henke G, Myssina S, Krikov M, Huber SM, Wieder T, Lang F: Enhanced susceptibility to erythrocyte "apoptosis" following phosphate depletion. Pflugers Arch 2004;448:471-477.

106 Zappulla D: Environmental stress, erythrocyte dysfunctions, inflammation, and the metabolic syndrome: adaptations to $\mathrm{CO}_{2}$ increases? J Cardiometab Syndr 2008;3:30-34.

107 Abed M, Towhid ST, Mia S, Pakladok T, Alesutan I, Borst O, Gawaz M, Gulbins E, Lang F: Sphingomyelinaseinduced adhesion of eryptotic erythrocytes to endothelial cells. Am J Physiol Cell Physiol 2012;303:C991999.

108 Bottger E, Multhoff G, Kun JF, Esen M: Plasmodium falciparum-infected erythrocytes induce granzyme B by NK cells through expression of host-Hsp70. PLoS One 2012;7:e33774.

109 Firat U, Kaya S, Cim A, Buyukbayram H, Gokalp O, Dal MS, Tamer MN: Increased caspase-3 immunoreactivity of erythrocytes in STZ diabetic rats. Exp Diabetes Res 2012;2012:316384. 


\section{Kidney \\ Blood Pressure Research}

Malik/Bissinger/Calabrò/Faggio/Jilani/Lang: Aristolochic Acid-Induced Eryptosis

110 Ganesan S, Chaurasiya ND, Sahu R, Walker LA, Tekwani BL: Understanding the mechanisms for metabolism-linked hemolytic toxicity of primaquine against glucose 6-phosphate dehydrogenase deficient human erythrocytes: evaluation of eryptotic pathway. Toxicology 2012;294:54-60.

111 Gao M, Cheung KL, Lau IP, Yu WS, Fung KP, Yu B, Loo JF, Kong SK: Polyphyllin D induces apoptosis in human erythrocytes through $\mathrm{Ca}(2)(+)$ rise and membrane permeabilization. Arch Toxicol 2012;86:741752.

112 Ghashghaeinia M, Cluitmans JC, Akel A, Dreischer P, Toulany M, Koberle M, Skabytska Y, Saki M, Biedermann T, Duszenko M, Lang F, Wieder T, Bosman GJ: The impact of erythrocyte age on eryptosis. Br J Haematol 2012;157:606-614.

113 Jilani K, Lupescu A, Zbidah M, Abed M, Shaik N, Lang F: Enhanced Apoptotic Death of Erythrocytes Induced by the Mycotoxin Ochratoxin A. Kidney Blood Press Res 2012;36:107-118.

114 Jilani K, Lupescu A, Zbidah M, Shaik N, Lang F: Withaferin A-stimulated Ca ${ }^{2+}$ entry, ceramide formation and suicidal death of erythrocytes. Toxicol In Vitro 2013;27:52-58.

115 Kucherenko YV, Lang F: Inhibitory Effect of Furosemide on Non-Selective Voltage-Independent Cation Channels in Human Erythrocytes. Cell Physiol Biochem 2012;30:863-875.

116 Lang E, Qadri SM, Jilani K, Zelenak C, Lupescu A, Schleicher E, Lang F: Carbon monoxide-sensitive apoptotic death of erythrocytes. Basic Clin Pharmacol Toxicol 2012;111:348-355.

117 Lupescu A, Jilani K, Zbidah M, Lang E, Lang F: Enhanced Ca(2+) Entry, Ceramide Formation, and Apoptotic Death of Erythrocytes Triggered by Plumbagin. J Nat Prod 2012;75:1956-1961.

118 Lupescu A, Jilani K, Zbidah M, Lang F: Induction of apoptotic erythrocyte death by rotenone. Toxicology 2012;300:132-137.

119 Polak-Jonkisz D, Purzyc L: Ca Influx versus Efflux during Eryptosis in Uremic Erythrocytes. Blood Purif 2012;34:209-210.

120 Qian EW, Ge DT, Kong SK: Salidroside protects human erythrocytes against hydrogen peroxide-induced apoptosis. J Nat Prod 2012;75:531-537.

121 Shaik N, Zbidah M, Lang F: Inhibition of $\mathrm{Ca}(2+)$ entry and suicidal erythrocyte death by naringin. Cell Physiol Biochem 2012;30:678-686.

122 Vota DM, Maltaneri RE, Wenker SD, Nesse AB, Vittori DC: Differential erythropoietin action upon cells induced to eryptosis by different agents. Cell Biochem Biophys 2013;65:145-157.

123 Weiss E, Cytlak UM, Rees DC, Osei A, Gibson JS: Deoxygenation-induced and Ca(2+) dependent phosphatidylserine externalisation in red blood cells from normal individuals and sickle cell patients. Cell Calcium 2012;51:51-56.

124 Zbidah M, Lupescu A, Jilani K, Lang F: Stimulation of suicidal erythrocyte death by fumagillin. Basic Clin Pharmacol Toxicol 2013;112:346-351.

125 Zbidah M, Lupescu A, Shaik N, Lang F: Gossypol-induced suicidal erythrocyte death. Toxicology 2012;302:101-105.

126 Zelenak C, Pasham V, Jilani K, Tripodi PM, Rosaclerio L, Pathare G, Lupescu A, Faggio C, Qadri SM, Lang F: Tanshinone IIA stimulates erythrocyte phosphatidylserine exposure. Cell Physiol Biochem 2012;30:282294.

127 Abed M, Herrmann T, Alzoubi K, Pakladok T, Lang F: Tannic Acid induced suicidal erythrocyte death. Cell Physiol Biochem 2013;32:1106-1116.

128 Ahmed MS, Langer H, Abed M, Voelkl J, Lang F: The uremic toxin acrolein promotes suicidal erythrocyte death. Kidney Blood Press Res 2013;37:158-167.

129 Ghashghaeinia M, Cluitmans JC, Toulany M, Saki M, Koberle M, Lang E, Dreischer P, Biedermann T, Duszenko M, Lang F, Bosman GJ, Wieder T: Age Sensitivity of NFkappaB Abundance and Programmed Cell Death in Erythrocytes Induced by NFkappaB Inhibitors. Cell Physiol Biochem 2013;32:801-813.

130 Lupescu A, Jilani K, Zbidah M, Lang F: Patulin-induced suicidal erythrocyte death. Cell Physiol Biochem 2013;32:291-299.

131 Ahmed MS, Abed M, Voelkl J, Lang F: Triggering of suicidal erythrocyte death by uremic toxin indoxyl sulfate. BMC Nephrol 2013;14:244.

132 Voelkl J, Alzoubi K, Mamar AK, Ahmed MS, Abed M, Lang F: Stimulation of suicidal erythrocyte death by increased extracellular phosphate concentrations. Kidney Blood Press Res 2013;38:42-51. 